Pengaruh Dewan... (Gista, Ulfa)

\title{
PENGARUH DEWAN KOMISARIS, DEWAN PENGAWAS SYARIAH (DPS) DAN DIREKSI TERHADAP KINERJA MAQASID SYARIAH.
}

\author{
Gista Rismayani \\ Universitas Perjuangan \\ gista.unper@gmail.com \\ Ulfa Luthfia Nanda \\ Universitas Perjuangan \\ ulnanda@yahoo.com
}

\begin{abstract}
Abstrak
Kinerja Maqasid Syariah adalah hasil yang dijabarkan dari sebuah kerangka konseptual yang didasari dari teori maqasid syariah. Kinerja maqasid syariah hendaknya menjadi suatu upaya bagi lembaga keuangan syariah untuk menetapkan suatu tujuan yang tidak hanya berorientasi pada profit tetapi juga falah. Penelitian ini bertujuan untuk mengidentifikasi faktor-faktor apa saja yang mempengaruhi kinerja maqasid syariah di perbankan umum syariah di Indonesia. Variabel dependen yang digunakan dalam penelitian ini adalah Kinerja Maqasid Syariah sedangkan variabel independen dalam penelitian ini meliputi kinerja dewan komisaris, kinerja DPS, dan kinerja direksi. Populasi penelitian adalah perbankan umum syariah yang terdaftar di Bank Indonesia. Menggunakan teknik purposive sampling diperoleh 7 bank syariah yang menjadi objek dalam penelitian ini. Aregresi data panel dengan aplikasi Eviews 9. Hasil penelitian menunjukkan bahwa variabel kinerja dewan komisaris, DPS dan direksi tidak berpengaruh terhadap kinerja maqasid syariah.
\end{abstract}

Sharia Maqasid Performance is the result described from a conceptual framework based on sharia maqasid theory. A maqasid sharia performance should be an effort for Islamic financial institutions to establish a goal that not only profit-oriented but also falah. This study aims to identify factors affecting the sharia maqasid performance of Islamic banking in Indonesia. The dependent variable used in this study is sharia maqasid performance and the independent variables in this study areboard of commissioners performance, Sharia Supervisory Board Performance, and board of directors performance. The study population is sharia banking registered in Bank Indonesia. Using purposive sampling technique obtained 7 islamic banking which become object in this research.The data analysis using panel data regression by Eviews 9. The results indicates that the variables of board of commissioners performance, sharia board performance. and board of directors performance have no significant effect toward the Sharia Maqasid Performance. 


\section{PENDAHULUAN}

Kehadiran instansi keuangan berbasis syariah kini menjadi kekuatan bagi perekonomian Islam di dunia. Salah satu instansi keuangan syariah yang berada di Indonesia adalah perbankan. Tidak hanya perbankan konvensioanl, kini perbankan syariah menunjukkan eksistensinya sebagai perbankan yang tidak menganut riba. Indonesia dengan penduduk mayoritas muslim diharapkan dapat mendorong perekonomian melalui pertumbuhan perbankan syariahnya. Sampai saat ini perbankan syariah di Indonesia telah memiliki jumlah BUS sebanyak 13, UUS 22, dan BPRS 165.

Penilaian kinerja perbankan syariah hingga saat ini masih melihat hanya dari satu sisi saja yaitu sisi keuangan saja (Bedoui, 2012). Hal tersebut menjadi tidak berbeda dengan perbankan konvensional dalam menilai kinerjanya. Belum adanya tola ukur pengukuran berbasis syariah, menyebabkan perbankan syariah masih mengadopsi tolak ukur kinerja keuangan yang sama dengan perbankan konvensional

Hal ini menjadi tidak berbeda dengan perbankan konvensional dalam menilai rasio keuangan sebagai suatu pencapaian kinerja. Hingga saat ini, perbankan syariah masih mengadopsi tolak ukur konvensional untuk mengukur kinerjanya. Hal ini memperlihatkan bahwa tujuan dari perbankan syariah masih bias dan belum adanya upaya yang serius untuk memberikan solusi yang tepat dari permasalahan ini. Akibatnya, sampai saat ini kinerja perbankan syariah dinilai tertinggal dari bank konvensional. Padahal, perbankan syariah memiliki tujuan yang berbeda dengan perbankan konvesional sehingga apabila dibandingkan hanya dari sisi keuangan saja perbankan syariah belum mampu untuk mengungguli perbankan konvensional. penelitian yang dilakukan Mokhtar et.al (2006) mengungkapkan bahwa bank syariah dinilai kurang efisien dibandingkan dengan perbankan konvensional. Selain itu, penelitian lain oleh Samad (1999) mengemukakan hal yang serupa bahwa tingkat efisiensi bank konvensional lebih tinggi dibandingkan perbankan syariah di Malaysia. Penelitian Mohammed \& Taib (2015) membandingkan kinerja 12 bank syariah dan 12 bank konvensional di Malaysia dengan menggunakan model PMMS (Performance Measures Based on Maqasid Al-Shariah Fraework) dan model CBPM (ROA, NII, LIQ) menunjukkan bahwa model PMMS yang digunakan bank syariah menunjukkan kinerja yang lebih baik dari pada kinerja bank konvensional sedangkan apabila pengukuran kinerja menggunakan model CBPM, bank syariah menghasilkan kinerja yang lebih rendah dibandingkan bank konvensional yang menggunakan ROA, NII, LIQ untuk melihat kinerjanya.Fenomena tersebut menunjukkan bahwa perbankan syariah akan lebih relevan apabila melihat kinerja dengan menggunakan pendekatan yang sesuai dengan tujuannya.

Pengelolaan perbankan syariah tidak terlepas dari pihak yang bertugas untuk mengawasi segala kegiatan bank syariah. Oleh karena itu, adanya tata kelola yang baik dapat tercermin dari kinerja yang diperoleh oleh bank syariah. UU No.21 Tahun 2008 tentangPerbankan Syariah, yaitu khususnya di Bab V bagian Dewan Pengawas Syariah (DPS) disebutkan bahwa DPS diberikan wewenang untuk melakukan pengawasan dan penasehatan atas kepatuhan prinsip syariah seluruh aktivitas bank syariah. Hameed, et.al (2004) menyatakan bahwa dewan pengawas memiliki peran yang sangat penting dalam memastikan bank syariah tidak menyimpang dari aturan syariah.Keberadaan DPS di bank adalah sebuah keharusan. Dengan demikian, keberadaan DPS di bank syariahmerupakan salah satu unsur dari kepatuhan syariah. Musibah \& Sulaiman (2014) berpendapat bahwa dibentuknya DPS adalah untuk 
memastikan bahwa transaksi didasarkan pada prinsip-prinsip Islam karena apabila tidak, bank syariah akan kehilangan kepercayaan masyarakat.

Selain DPS, good corporate governance sebuah organisasi tidak terlepas dari peran dewan komisaris dan dewan direksi. Menurut Kholid dan Bachtiar (2015), dewan komisaris secara tidak langsung memiliki peran dalam pengawasan kepatuhan syariah. Peraturan Bank Indonesia Nomor 11/33/PBI/2009 mengungkapkan tugas dewan komisaris yakni memastikan bahwa Direksi telah menindaklanjuti temuan audit dan/atau rekomendasi dari hasil pengawasan Bank Indonesia, auditor intern, Dewan Pengawas Syariah dan/atau auditor eksternal. Sementara itu, dewan direksi memiliki tugas tanggung jawab yakni bertanggung jawab penuh atas pelaksanaan pengelolaan Bank Umum Syariah (BUS) berdasarkan prinsip kehati-hatian dan Prinsip Syariah. Oleh karena itu, fungsi anggota dewan dalam sebuah tata kelola perlu dikaji apakah kinerja dari anggota dewan telah dilaksanakan sesuai dengan peraturan atau belum. Hal tersebut dapat tecermin dari seberapa besar kontribusi yang dilakukan anggota dewan dalam melaksanakan fungsinya untuk bank syariah dari seberapa sering mereka melakukan pertemuan untuk membahas segala bentuk kegiatan operasional bank syariah.

Mohammed et al (2008) telah mengembangkan teori maqasid syariah oleh Zahrah (1958) menjadi sebuah ukuran kinerja yang dapat digunakan untuk menilai suatu kinerja perbankan syariah. Penelitian yang dilakukan oleh Mohammed \& Taib (2015) menggunakan pendakatan Sharia Maqasid Indexuntuk mengukur kinerja perbankan syariah dan dapat digunakan sebagai acuan untuk menilai kinerja perbankan syariah yang lebih relevan.

Kinerja maqasid syariah merupakan penilaian kinerja yang ditinjau dari aspek keuangan dan non keuangan yang bersumber dari tujuan maqasid syariah. Ketiga tujuan tersebut adalah mendidik individu, menegakkan keadilan, dan kepentingan publik.

Penelitian ini bermaksud untuk mengetahui kinerja dewan dalam sebuah tata kelola perbankan dalam pengaruhnya terhadap kinerja maqasid syariah. Penelitian ini menjadi penting untuk dilakukan ketika fenomena yang ada di Indonesia menunjukkan belum adanya kerangka konseptual yang mengacu pada prinsipprinsip syariah.Beberapa penelitian tentang kinerja maqasid syariah telah dilakukan oleh Antonio et al. (2012), Al Gifari et.al (2015), Afrinaldi (2013), Kholid dan Bachtiar (2015). Pengukuran kinerja maqasid syariah yang telah dikembangkan oleh Mohammed et.al (2008) menjadi tolak ukur bagi beberapa peneliti untuk menilai kinerja perbankan syariah dari perspektif tujuan maqasid al sharia. Penelitian ini akan mengidentifikasi seberapa besar kinerja dewan komisaris, DPS dan Direksiberpengaruh terhadap kinerja maqasid syariah.

\section{KERANGKA TEORITIS Sharia Enterprise Theory}

Akuntansi syariah tidak hanya sebagai bentuk pertanggungjawaban kepada pemilik perusahaan, tetapi juga pertanggung jawaban kepada Tuhan. Sharia enterprise theory mengandung nilai keadilan, kebenaran, kejujuran, amanah, dan pertanggungjawaban, dan bentuk pertanggungjawaban tersebut adalah pertanggngjawaban kepada Allah SWT (Triyuwono 2012). Sharia enterprise theory menurutTriyuwono (2012) menjelaskan bahwa aksioma terpenting yang harus mendasari dalam setiap penetapan konsepnya adalah Allah sebagai Pencipta dan Pemilik Tunggal dari seluruh sumber daya yang ada di dunia ini. Sedangkan sumber daya yang dimiliki oleh para stakeholders pada prinsipnya adalah amanah 
dari Allah SWT yang didalamnya melekat tanggung jawab untuk digunakan dengan cara dan tujuan yang ditetapkan oleh Sang Pemberi Amanah.

Implikasi dalam penelitian ini adalah bank syariah diharapkan tidak menempatkan profit diatas segala-galanya dalam pencapian kinerjanya. Selain kinerja keuangan, bank syariah diharapkan dapat meningkatkan kinerja sosialnya sesuai dengan tujuan maqasid syariah. Karena dalam menjalankan aktivitasnya bank syariah tidak hanya bertanggung jawab kepada stakeholders melainkan kepada Allah SWT lah yang paling utama.

Maqasid al-sharia menjadi suatu landasan untuk perkembangan ekonomi islam. Tiga pilar tujuan maqasid syariah menjadi acuan untuk membentuk suatu kinerja perbankan syariah yang lebih efektif dan sesuai dengan syariah islam. Dengan penilaian kinerja perbankan syariah melalui pendekatan maqasid indeks, diharapkan bank syariah dalam menerapkan prinsipprinsip syariah dapat dilihat sejauh mana pencapaiannya untuk meningkatkan keadilan dan kemaslahatan untuk masyarakat.

\section{HIPOTESIS}

\section{Hubungan Kinerja Dewan Komisaris Terhadap Kinerja Maqasid Syariah}

Dewan komisaris berwenang dalam memberikan saran dan melakukan pengawasan terhadap tugas dan tanggung jawab direksi. Dewan komisaris akan memantau dan memastikan apakah direksi telah menindaklanjuti temuan yang diperoleh dan direkomendasikan oleh DPS mengenai kepatuhan bank syariah yang menjalankan kegiatannya sesuai dengan prinsip Islam. Ntim \& Osei (2011) dalam penelitiannya mengemukakan bahwa adanya hubungan positif signifikan antara frekuensi pertemuan dewan dengan kinerja perusahaan. Hal ini menunjukan bahwa anggota dewan yang melakukan pertemuan lebih sering cenderung menghasilkan kinerja yang lebih baik. Kharis dan Suhardjanto (2012) mengatakan hal yang serupa bahwa semakin tinggi frekuensi pertemuan dewan komisaris, hal itu dapat meningkatkan kinerja perusahaan. Dengan demikian adanya pertemuan dewan komisaris merupakan wadah untuk melakukan pengarahan, memantau, dan juga mengevaluasi pelaksanaan kebijakan bank syariah termasuk dalam pelaksanaan fungsi kepatuhan bank syariah.

Berdasarkan uraian tersebut diatas, maka hipotesis yang diajukan adalah sebagai berikut:

\section{H1:Kinerja dewan komisarisberpengaruh positif terhadap kinerja maqasid syariah.}

\section{Hubungan Kinerja DPS terhadap Kinerja Maqasid Syariah}

Keberadaan DPS di bank syariah merupakan salah satu unsur dari kepatuhan syariah. Menurut Hameed, et.al., (2004), keberadaan DPS di bank adalah sebuah keharusan. Adanya peran DPS dalam perbankan syariah merupakan aspek yang sangat pentng karena hal ini menyangkut reputasi perbankan syariah dimata masyarakat sebagai cerminan bagi bank syariah yang telah melaksanakan prinsip syariah dalam kegiatannya (Satifa dan Suprapto, 2014). Kholid dan Bachtiar (2015) menyatakan bahwa mekanisme dewan pengawas syariah dapat meningkatkan Kinerja maqasid syariah. Dalam melaksanakan fungsinya, DPS harus malakukan pertemuan minimal satu kali dalam satu bulan. Pertemuan yang dilakukan DPS akan mencerminkan sebarapa baik kinerja DPS dalam melaksanakan tugas dan tanggung jawabnya.

Berdasarkan uraian tersebut diatas, maka hipotesis yang diajukan adalah sebagai berikut: 
H2 : Kinerja DPS berpengaruh positif terhadap kinerja maqasid syariah

\section{HubunganKinerjaDewan \\ Direksi \\ Terhadap Kinerja Maqasid Syariah}

Dalam tata kelola, direksi memainkan peran penting dalam memantau dan juga menasehati manajemen dalam perumusan dan pelaksanaan strategi.Dalam PBI No.11/33/PBI/2009 disebutkan bahwa Direksi bertanggung jawab penuh atas pelaksanaan pengelolaan BUS berdasarkan prinsip kehati-hatian dan Prinsip Syariah. Adanya rapat direksi, memberikan jalan bagi anggota dewan untuk berkumpul dan merencanakan strategi untuk memantau kegiatan manajemen dan dan operasional bank (Kama \& Cuku, 2009). Temuan oleh Ntim \& Osei (2011) menunjukkan bahwa dewan perusahaan yang lebih sering melakukan pertemuan memiliki kapasitas yang baik dalam memberikan saran, memantau, dan juga mendisiplinkan manajemen sehingga meningkatkan kinerja perusahaan. Semakin tinggi intensitas rapat yang dilakukan oleh direksi, maka pencapaian sebuah kinerja bank syariah akan semakin tinggi.

Berdasarkan uraian tersebut diatas, maka hipotesis yang diajukan adalah sebagai berikut:

\section{H3 : Kinerja dewan direksi berpengaruh positif terhadap kinerja maqasid syariah}

\section{METODOLOGI}

\section{Metode Penelitian}

Jenis penelitian yang dilakukan dalam penelitian ini adalah kuantitatif yaitu metode penelitian yang berlandaskan pada filsafat positivisme, digunakan untuk meneliti pada populasi atau sampel tertentu,pengumpulan data menggunakan instrumen penelitian, analisis data bersifat kuantitatif/statistik, dengan tujuan untuk menguji hipotesis yang telah ditetapkan (Sugiyono, 2012:8)

\section{Jenis dan Sumber Data}

Data yang digunakan dalam penelitian ini adalah data sekunder. Sumber data yang digunakan dalam penelitian ini adalah laporan tahunan dan laporan tata kelola perbankan umum syariah tahun 2011-2015 yang diperoleh dari masing-masing website bank syariah.

\section{Populasi dan Sampel}

Populasi dalam penelitian ini adalah 7 Bank Umum Syariah (BUS) di Indonesia, dimana Penarikan sampel dilakukan dengan menggunakan metode purposive sampling.

\section{Definisi Operasional dan Pengukuran Variabel}

\section{Kinerja Maqasid Syariah}

Kinerja maqasid syariah merupakan penilaian kinerja yang ditinjau dari aspek keuangan dan non keuangan yang bersumber dari tiga tujuan maqasid syariah yaitu mendidik individu, menegakkan keadilan, dan kepentingan publik/maslahah.

Tujuan maqasid syariah berdasarkan konsep tujuan maqasid syariah oleh Zahrah (1958) meliputi Tahdzib al-Fard (mendidik individu), Iqamah Al-Adl (menetapkan keadilan), dan Maslahah (kesejahteraan). Mohammed et al (2008) telah membuat suatu pengukuran kinerja berdasarkan pendekatan Sharia Maqasid Index. Dari ketiga tujuan maqasid syariah, Mohammed et al (2008) menerjemahkannya ke dalam dimensi kemudian diklasifikasikan menjadi beberapa elemen dan diubah menjadi rasio kinerja dalam bentuk Sharia Maqasid Index (SMI).

Tujuan yang pertama adalah Tahdzib alFard Education (mendidik individu) yaitu bank syariah harus melakukan pengembangan pengetahuan dan 
keterampilan serta menanamkan dalam nilainilai individu untuk perkembangan spiritualnya. Oleh karena itu, bank syariah harus merancang program pendidikan dan pelatihan yang dapat mengembangkan tenaga kerja yang berpengetahuan dan terampil serta memiliki dengan nilai-nilai moral yang baik. (Mohammed \& Taib, 2015).

Tujuan maqasid syariah yang kedua yaitu Iqamah Al-Adl (menetapkan keadilan) yaitu bank syariah harus memastikan transaksi yang dilakukan sudah wajar dalam semua kegiatan usahanya. Selain itu juga bank syariah harus memastikan bahwa semua usaha bisnisnya bebas dari unsurunsur negatif yang dapat menciptakan ketidakadilan, seperti riba, penipuan, korupsi, dan sebagainya. Secara tidak langsung juga, bank syariah harus bijak dalam menggunakan keuntungannya dan secara langsung mengarahkan kegiatannya pada area utama yang dapat membantu mengurangi ketidakseimbangan pendapatan dan kekayaan dan mendorong distribusi modal dan kekayaan. (Mohammed \& Taib, 2015).

Maqasid ketiga yaitu Maslahah (kesejahteraan) yaitu bank syariah harus memberikan prioritas untuk kegiatan usaha yang menghasilkan keuntungan yang lebih besar kepada masyarakat umum. Hal ini termasuk kegiatan di bidang yang terkait dengan kebutuhan pokok masyarakat seperti investasi di sektor riil, pembiayaan proyekproyek perumahan, dan sebagainya (Mohammed \& Taib, 2015).

Kinerja maqasid syariah diukur berdasarkan Sharia Maqasid Index. Berikut ini adalah tabel model pengukuran Sharia Maqasid Index:

Tabel 1

Model Pengukuran Indeks Maqasid Syariah

\begin{tabular}{|c|c|c|c|c|}
\hline Tujuan & Dimensi & Elemen & Rasio Kinerja & Sumber data \\
\hline \multirow{8}{*}{$\begin{array}{l}\text { Mendidik } \\
\text { Individu }\end{array}$} & \multirow{3}{*}{$\begin{array}{l}\text { D1.Pengembangan } \\
\text { Pengetahuan }\end{array}$} & \multirow[t]{3}{*}{ E1. Pendidikan } & R1.Beasiswa & \multirow[t]{2}{*}{ Laporan Tahunan } \\
\hline & & & $\begin{array}{l}\text { Pendidikan/Total } \\
\text { Operasional }\end{array}$ & \\
\hline & & & & \multirow[t]{2}{*}{ Laporan Tahunan } \\
\hline & \multirow{2}{*}{$\begin{array}{l}\text { D2.Menambah } \\
\text { meningkatkan keterampilan } \\
\text { baru }\end{array}$} & \multirow[t]{2}{*}{ E2. Penelitian } & R2.Biaya Penelitian/Total & \\
\hline & & & Biaya Opersional & \multirow[t]{3}{*}{ Laporan Tahunan } \\
\hline & \multirow{3}{*}{$\begin{array}{l}\text { D3.Menciptakan kesadaran } \\
\text { masyarakat akan keberadaan } \\
\text { bank syariah }\end{array}$} & E3. Pelatihan & R3.Biaya Pelatihan/Total & \\
\hline & & & biaya Operasional & \\
\hline & & E4. Publisitas & $\begin{array}{l}\text { R4.Biaya Publisitas/Total } \\
\text { biaya Operasional }\end{array}$ & Laporan Tahunan \\
\hline \multirow{8}{*}{$\begin{array}{l}\text { Mew } \\
\text { dilan }\end{array}$} & \multirow[t]{3}{*}{ D4. Kontrak yang adil } & E5.Pengembangan & Equalization & \multirow{4}{*}{$\begin{array}{l}\text { Laporan Tahunan } \\
\text { Laporan Tahunan }\end{array}$} \\
\hline & & yang adil & $(\mathrm{PER}) / \mathrm{Net} \quad$ or & \\
\hline & & & Investment Income & \\
\hline & \multirow[t]{3}{*}{$\begin{array}{l}\text { D5. Produk dan Jasa yang } \\
\text { Terjangkau }\end{array}$} & & & \\
\hline & & E6.Distribusi & R6.Pembiayaan Mudharabah & \\
\hline & & Fungsional & $\begin{array}{ll}\text { dan } & \text { Musyarakah/Total } \\
\text { Investasi } & \end{array}$ & Laporan Tahunan \\
\hline & \multirow{2}{*}{$\begin{array}{l}\text { D6. Penghapusan atas } \\
\text { ketidakadilan }\end{array}$} & & & \\
\hline & & $\begin{array}{l}\text { E7.Produk Bank Non } \\
\text { Bunga }\end{array}$ & $\begin{array}{l}\text { R7. Pendapatan Non } \\
\text { Bunga/Total Pendapatan }\end{array}$ & \\
\hline \multirow[t]{3}{*}{3.} & D7. Profitabilitas & E8. Rasio Laba & R8.Laba Bersih/Total Aktiva & Laporan Tahunan \\
\hline & $\begin{array}{l}\text { D8.Distribusi Pendapatan dan } \\
\text { Kekayaan }\end{array}$ & $\begin{array}{l}\text { E9.Pendapatan } \\
\text { Personal }\end{array}$ & R9.Zakat/Net Asset & Laporan Tahunan \\
\hline & D9. Investasi pada Sektor Riil & $\begin{array}{l}\text { E10. Rasio Investasi } \\
\text { pada Sektor Riil }\end{array}$ & $\begin{array}{l}\text { R10.Investasi Ekonomi } \\
\text { Sektor Riil/Total Investasi }\end{array}$ & Laporan Tahunan \\
\hline
\end{tabular}

Sumber : Mohammed. et al. (2008); Antonio et al (2012) 
Hasil pengukuran Sharia Maqasid Index berdasarkan bobot rata-rata pada masing-masing dimensi dan elemen mengacu pada penelitian yang dilakukan oleh Mohammed et al (2008). Berikut ini rata-rata bobot yang diberikan oleh para ahli.

\section{Tabel 2.}

Bobot rata-rata domensi dan elemen Sharia Maqasid Index

\begin{tabular}{|c|c|c|c|c|}
\hline Tujuan & Dimensi & $\begin{array}{c}\text { Bobot } \\
\text { Rata- } \\
\text { rata }\end{array}$ & Elemen & $\begin{array}{c}\text { Bobot } \\
\text { Rata-rata }\end{array}$ \\
\hline \multirow{11}{*}{$\begin{array}{l}\text { 1. Mendidik } \\
\text { Individu }\end{array}$} & D1.Pengembangan & \multirow{11}{*}{30} & E1. Pendidikan & 24 \\
\hline & Pengetahuan & & E2. Penelitian & 27 \\
\hline & & & & 51 \\
\hline & D2.Menambah dan & & E3. Pelatihan & 26 \\
\hline & $\begin{array}{l}\text { menıngkatKan } \\
\text { keterampilan baru }\end{array}$ & & & \\
\hline & & & & \\
\hline & D3.Menciptakan & & E4. Publisitas & 23 \\
\hline & kesadaran & & & \\
\hline & masyarakat & & & \\
\hline & keberadaan bank & & & \\
\hline & & & Total & 100 \\
\hline \multirow[t]{7}{*}{$\begin{array}{l}\text { 2. Mewujudk } \\
\text { an Keadilan }\end{array}$} & $\begin{array}{l}\text { D4. Kontrak yang } \\
\text { adil }\end{array}$ & \multirow{7}{*}{41} & $\begin{array}{l}\text { E5.Pengembangan } \\
\text { yang adil }\end{array}$ & 30 \\
\hline & D5. Produk dan & & E6.Distribusi & 32 \\
\hline & yang & & Fungsional & \\
\hline & Terjangkau & & & \\
\hline & D6. Penghapusan & & E7.Produk Bank Non & 38 \\
\hline & & & Total & \\
\hline & & & & 100 \\
\hline \multirow{8}{*}{$\begin{array}{l}\text { 3. Kepenting } \\
\text { an Publik }\end{array}$} & D7. Profitabilitas & & E8. Rasio Laba & 30 \\
\hline & D8.Distribusi & \multirow{5}{*}{29} & E9.Pendapatan & \\
\hline & Pendapatan & & Personal & 33 \\
\hline & Kekayaan & & & \\
\hline & D9. Investasi pada & & E10.Rasio Investasi & \\
\hline & Sektor Riil & & pada Sektor Riil & 37 \\
\hline & & & T & \\
\hline & & 100 & & 100 \\
\hline
\end{tabular}

Mohammed, et al (2008)

Secara matematis, dalam menentukan indikator kinerja dan mengetahui Sharia Maqasid Index berdasarkan tiga tujuan maqasid syariah dapat diperoleh dengan langkah-langkah sebagai berikut : 
1) Langkah pertama yaitu menghitung indikator kinerja tujuan pertama yaitu Tahzib al-Fard (Mendidik Individu).

IK (T1) = Error! Reference source not found. + Error! Reference source not found. + Error! Reference source not found. dimana,

Error! Reference source not found. = (Error! Reference source not found. $x$ Error! Reference source not found. $\times$ Error! Reference source not found.)

Error! Reference source not found. =Error! Reference source not found. $x$ Error! Reference source not found. $x$ Error! Reference source not found.)

Error! Reference source not found. = (Error! Reference source not found.x Error! Reference source not found.)

Error! Reference source not found. = (Error! Reference source not found. $x$ Error! Reference source not found. $\times$ Error! Reference source not found.)

Keterangan:

$\mathrm{IK}(\mathrm{T} 1)=$ Indikator kinerja tujuan pertama dari Maqasid Syariah yaitu mendidik individu.

Error! Reference source not found. = Bobot rata-rata untuk tujuan pertama yaitu mendidik individu ditujukan pada tabel 3.2. bobot untuk tujuan pertama yaitu sebesar $30 \%$

Error! Reference source not found. = Bobot rata-rata untuk elemen pertama yaitu pendidikan dari tujuan pertama yaitu mendidik individu ditujukan pada tabel 3.2 yaitu sebesar $24 \%$

Error! Reference source not found. = Bobot rata-rata untuk elemen kedua yaitu penelitian dari tujuan pertama yaitu mendidik individu ditujukan pada tabel 3.2 yaitu sebesar $27 \%$

Error! Reference source not found. = Bobot rata-rata untuk elemen ketiga yaitu pelatihan dari tujuan pertama yaitu mendidik individu ditujukan pada tabel 3.2 yaitu sebesar $26 \%$

Error! Reference source not found. = Bobot rata-rata untuk elemen keempat yaitu publisitas dari tujuan pertama yaitu mendidik individu ditujukan pada tabel 3.2 yaitu sebesar $23 \%$

Error! Reference source not found. = Rasio kinerja untuk elemen pertama yaitu pendidikan dari tujuan pertama yaitu mendidik individu. Diukur berdasarkan perhitungan besiswa pendidikan terhadap biaya operasional

Error! Reference source not found. = Rasio kinerja untuk elemen kedua yaitu penelitian dari tujuan pertama yaitu mendidik individu. Diukur berdasarkan perhitungan biaya penelitian terhadap biaya operasional

Error! Reference source not found. = Rasio kinerja untuk elemen ketiga yaitu pelatihan untuk tujuan pertama yaitu mendidik individu. Diukur berdasarkan perhitungan biaya pelatihan terhadap total biaya operasional.

Error! Reference source not found. = Rasio kinerja untuk elemen keempat yaitu publisitas untuk tujuan pertama yaitu mendidik individu. Diukur berdasarkan perhitungan biaya publisitas terhadap total biaya operasional.

2) Langkah kedua yaitu menghitung indikator kinerja tujuan kedua yaitu Iqamah al-Adl (Menegakkan Keadilan) $\mathrm{IK}(\mathrm{T} 2)$ = Error! Reference source not found. + Error! Reference source not found. , dimana

Error! Reference source not found. $=($ Error! Reference source not found. $x$ Error! Reference source not found. $\times$ Error! Reference source not found.) 
Error! Reference source not found. = (Error! Reference source not found.x Error! Reference source not found.x Error! Reference source not found.) Error! Reference source not found. = (Error! Reference source not found.x Error! Reference source not found.

Keterangan:

$\mathrm{IK}(\mathrm{T} 2)$ = Indikator kinerja tujuan kedua dari Maqasid Syariah yaitu mewujudkan keadilan.

Error! Reference source not found. = Bobot rata-rata untuk tujuan kedua yaitu mewujudkan keadilan ditujukan pada tabel 3.2. bobot untuk tujuan kedua yaitu sebesar $41 \%$

Error! Reference source not found. = Bobot rata-rata untuk elemen pertama yaitu pengembangan yang adil dari tujuan kedua mewujudkan keadilan ditujukan pada tabel 3.2 yaitu sebesar $30 \%$

Error! Reference source not found. = Bobot rata-rata untuk elemen kedua yaitu distribusi fungsional dari tujuan kedua mewujudkan keadilan ditujukan pada tabel 3.2 yaitu sebesar $32 \%$

Error! Reference source not found. = Bobot rata-rata untuk elemen ketiga yaitu produk bank non bunga dari tujuan kedua mewujudkan keadilan ditujukan pada tabel 3.2 yaitu sebesar $38 \%$

Error! Reference source not found. = Rasio kinerja untuk elemen pertama yaitu pengembangan yang adil dari tujuan kedua yaitu mendidik mewujudkan keadilan. Diukur berdasarkan perhitungan PER (Profit Equalization Reserves) terhadap Net or Invesment Income

Error! Reference source not found. = Rasio kinerja untuk elemen kedua yaitu distribusi fungsional dari tujuan kedua yaitu mendidik mewujudkan keadilan. Diukur berdasarkan perhitungan pembiayaan mudharabah dan musyarakah terhadap total pembiayaan

Error! Reference source not found. = Rasio kinerja untuk elemen ketiga yaitu produk bank non bunga dari tujuan kedua yaitu mendidik mewujudkan keadilan. Diukur berdasarkan perhitungan pendapatan non bunga terhadap total pendapatan.

3) Langkah ketiga yaitu menghitung indikator kinerja tujuan ketiga yaitu Jalb al Maslahah (Kepentingan Publik)

$\mathrm{IK}(\mathrm{T} 3)$ = Error! Reference source not found. + Error! Reference source not found. , dimana

Error! Reference source not found.= Error! Reference source not found. $x$ Error! Reference source not found. $\times$ Error! Reference source not found.) Error! Reference source not found. = (Error! Reference source not found.x Error! Reference source not found. $x$ Error! Reference source not found.) Error! Reference source not found. = (Error! Reference source not found. $x$ Error! Reference source not found.

Keterangan:

$\mathrm{IK}(\mathrm{T} 3)$ = Indikator kinerja tujuan ketiga dari Maqasid Syariah yaitu kepentingan publik.

Error! Reference source not found. = Bobot rata-rata untuk tujuan ketiga yaitu kepentingan publik ditujukan pada tabel 3.2. bobot untuk tujuan kedua yaitu sebesar $29 \%$

Error! Reference source not found. = Bobot rata-rata untuk elemen pertama yaitu rasio laba dari tujuan ketiga yaitu kepentingan publik ditujukan pada tabel 3.2 yaitu sebesar $30 \%$

Error! Reference source not found. = Bobot rata-rata untuk elemen kedua yaitu pendapatan personal 
dari tujuan ketiga yaitu kepentingan publik ditujukan pada tabel 3.2 yaitu sebesar $33 \%$

Error! Reference source not found. = Bobot rata-rata untuk elemen ketiga yaitu rasio pada investasi riil dari tujuan ketiga yaitu kepentingan publik ditujukan pada tabel 3.2 yaitu sebesar $37 \%$

Error! Reference source not found. = Rasio kinerja untuk elemen pertama yaitu rasio laba dari tujuan ketiga yaitu kepentingan publik. Diukur berdasarkan laba bersih terhadap total aktiva.

Error! Reference source not found. = Rasio kinerja untuk elemen kedua yaitu pendapatan personal dari tujuan ketiga yaitu kepentingan publik. Diukur berdasarkan Zakat yang dibayarkan bank syariah terhadap aktiva bersih.

Error! Reference source not found. = Rasio kinerja untuk elemen ketiga yaitu rasio investasi pada sektor riil dari tujuan ketiga yaitu kepentingan publik. Diukur berdasarkan perhitungan investasi ekonomi sektor riil terhadap total investasi.

4) Langkah kempat yaitu menghitung Sharia Maqasid Index

Berdasarkan rumus perhitungan indikator kinerja masing-masing tiga tujuan maqasid syariah di atas, maka untuk mengetahui Sharia Maqasid Index adalah total dari seluruh indikator kinerja tiga tujuan maqasid, maka dapat dirumuskan :

$\mathrm{SMI}=\mathrm{IK}(\mathrm{T} 1)+\mathrm{IK}(\mathrm{T} 2)+\mathrm{IK}(\mathrm{T} 3)$

\section{Kinerja Dewan Komisaris}

Dewan Komisaris adalah sebuah dewan yang bertugas melakukan pengawasan dan memberikan nasihat keada direktur. Dalam penelitian ini kinerja dewan komisaris diukur berdasarkan jumah rapat dewan komisaris. (Kharis dan Suhardjanto, 2012) 


\section{Kinerja DPS}

Dewan Pengawas Syariah (DPS) bertanggung jawab dalam memberikan saran dan nasihat kepada direksi serta mengawasi kegiatan bank syariah supaya sesuai prinsip syariah. Dalam menjalankan fungsinya, DPS minimal melakukan pertemuan sebulan sekali guna membahas produk bank syariah serta aktivitas operasional bank syariah. Dalam penelitian ini DPS diukur dengan jumlah rapat DPS. (Widayuni dan Harto, 2014).

\section{Kinerja Direksi}

Direksi bertanggung jawab penuh atas pelaksanaan pengelolaan Bank Umum Syariah (BUS) berdasarkan prinsip kehatihatian dan Prinsip Syariah. Dalam penelitian ini, kinerja direksi diukur berdasarkan jumlah rapat dewan direksi untuk setiap tahunnya. (Kama \& Chuku, 2009)

\section{Teknik Analisa Data}

Teknik analisis data dalam penelitian ini menggunakan statistik deskriptif, uji asumsi klasik (normalitas, multikolinearitas, autokorelasi, heterodeksitas), dan untuk pengujian hipotesis digunakan regresi berganda dengan data panel, dimana model persamaan regresinya sebagai berikut : $\wedge^{\wedge}$ Error! Reference source not found. = Error!

Reference source not found.+ Error! Reference source not found. + Error! Reference source not found. + Error! Reference source not

found. + Error! Reference source not found. Keterangan:

Error! Reference source not found. : Kinerja Maqasid

Error! Reference source not found. : Konstanta

Error! Reference source not found.: Koefisien Variabel Error! Reference source not found., Error! Reference source not found., Error! Reference source not found.

Error! Reference source not found. : Kinerja dewan komisaris

Error! Reference source not found. : Kinerja Dewan Pengawas Syariah (DPS)

Error! Reference source not found. : Kinerja Direksi

Error! Reference source not found. : variabel gangguan kombinasi time series dan cross section

i : unit cross section

t : periode waktu

\section{HASIL DAN PEMBAHASAN Statistik Deskriptif}

Statistik deskriptif untuk masing-masing variabel, baik variabel dependen maupun independen dapat dilihat dalam tabel 4.1.

Tabel 4.1

Statistik Deskriptif Variabel

\begin{tabular}{clcccc}
\hline No. & SMI & DK & DPS & DD \\
\hline 1 & Mean & 0,279969 & 16,48485 & 14,63636 & 44,93939 \\
\hline 2 & Median & 0,280920 & 13 & 14 & 45 \\
\hline 3 & Maximum & 0,322450 & 58 & 24 & 103 \\
\hline 4 & Minimum & 0,191390 & 2 & 7 & 19 \\
\hline
\end{tabular}

\section{Uji Asumsi Klasik}

Hasil uji asumsi klasik yang dilakukan diantaranya adalah uji normalitas, uji multikolinearitas, uji autokorelasi, dan uji heterodeksitas. Berdasarkan pengolahan data dengan menggunakan aplikasi eviews 9, seluruh uji asumsi klasik telah memenuhi syarat untuk dapat dilakukan regersi berganda. 


\section{Pengujian Hipotesis dan Pembahasan}

Berdasarkan hasil uji chow, uji hausman, dan uji breuch pagan-LM, diketahui bahwa model yang paling baik adalah fixed effect. Dengan demikian berikut adalah model persamaan yang diperoleh untuk fixed effect.:

\begin{tabular}{|c|c|c|c|}
\hline \multicolumn{4}{|c|}{ Hasil Uji Parsial (Uji t) } \\
\hline Variabel & Koefisien & t-Statistik & Prob. \\
\hline $\begin{array}{l}\text { Dependen: } \\
\text { SMI }\end{array}$ & & & \\
\hline Independen: & & & \\
\hline $\mathrm{C}$ & 0,299276 & & \\
\hline DK & 0,000611 & 1,114073 & 0,2768 \\
\hline DPS & $-0,001624$ & $-1,125422$ & 0,2720 \\
\hline DD & $-0,000125$ & $-0,437708$ & 0,6657 \\
\hline
\end{tabular}

Pengaruh variabel jumlah rapat dewan komisarias menghasilkan probabilitas kesalahan sebesar 0,2768>0,10. Dengan demikian, hipotesis keempat yang diajukan dalam penelitian ini yang berbunyi kinerja dewan komisaris berpengaruh positif dan signifikan pada $\alpha=10 \%$ terhadapkinerja maqasid syariahtidak dapat diterima.Jumlah rapat dewan komisaris menunjukkan arah koefisien positif yang artinya semakin tinggi intensitas rapat dewan komisaris maka kinerja maqasid syariah semakin tinggi. Namun, hasil penelitian ini menolak hipotesis yang diajukan yaitu rapat dewan komisaris berpengaruh positif signifikan terhadap kinerja maqasid syariah. Hasil penelitian ini menolak hasil penelitian yang dilakukan oleh Ntim \& Osei (2011) yang mengatakan bahwa jumlah pertemuan dewan berpengaruh positif terhadap kinerja perusahaan. Hasil penelitian ini menunjukkan bahwa banyak atau tidaknya jumlah rapat yang dilakukan oleh dewan komisaris tidak menjamin baiknya kinerja perbankan syariah sehingga dapat dikatakan bahwa rapat dewan komisaris yang diselenggarakan kurang efektif dalam meningkatkan kinerja maqasid perbankan syariah di Indonesia. Dengan konsep yang serupa, penelitian ini sejalan dengan penelitian yang dilakukan oleh Zahra dkk (2015) yang menyatakan bahwa jumlah rapat dewan komisaris tidak berpengaruh terhadap kinerja keuangan profitabilitas. Penelitian serupa dalam aspek tujuan sosial diungkapkan oleh Gestari (2014) hasil penelitian menunjukkan bahwa fekuensi rapat dewan komisaris tidak memberikan pengaruh terhadap Islamic Social Reporting pada Bank Umum Syariah di Indonesia.

Pengaruh variabel jumlah rapat DPS menghasilkan probabilitaskesalahan sebesar 0,2720>0,10. Dengan demikian, hipotesis kedua yang diajukan dalam penelitian ini yang berbunyi kinerja DPS berpengaruh positif dan signifikan pada $\alpha=10 \%$ terhadapkinerja maqasid syariahtidak dapat diterima.Hasil penelitian menunjukkan bahwa kinerja DPS yang diukur dengan jumlah rapat DPS tidak berpegaruh terhadap kinerja maqasid syariah. Hasil penelitian menunjukkan arah koefisien negatif yang artinya semakin tinggi intensitas jumlah rapat DPS maka akan semakin rendah kinerja maqasid syariah. Hasil penelitian ini menolak 
hipotesis yang diajukan yaitu jumlah rapat DPS berpengaruh positif terhadap kinerja maqasid syariah. Hal ini kemungkinan disebabkan terkait pembahasan yang dibahas dalam rapat DPS hanya memfokuskan pada produk-produk pembiayaan bank dan mengenai kepatuhan bank syariah pada prinsip-prinsip syariah sehingga manajemen perbankan syariah masih belum memberikan dampak yang positif untuk meningkatkan kinerjanya dalam segi tujuan sosial. Dengan konsep yang serupa, penelitian ini sejalan dengan penelitian yang dilakukan oleh Chariri 
(2012) yang menyatakan bahwa jumlah rapat dewan berpengaruh negatif signifikan terhadap pengungkapan Corporate Social Responsibility. Selain itu, penelitian serupa dalam aspek tujuan sosial diungkapkan oleh Rahayu dan Cahyati (2014) mengungkapkan bahwa jumlah rapat DPS berpengaruh terhadap pengungkapan Corporate Social Responsibility (CSR).Dengan demikian, penelitian ini menunjukkan bahwa tingginya frekuensi rapat yang dilakukan oleh DPS, tidak menentukan tingginya kinerja maqasid syariah di Indonesia.

Pengaruh variabel jumlah rapat dewan direksi menghasilkan probabilitaskesalahan sebesar 0,6577>0,10. Dengan demikian, hipotesis kedua yang diajukan dalam penelitian ini yang berbunyi kinerja dewan direksiberpengaruh positif dan signifikan pada $\alpha=10 \%$ terhadapkinerja maqasid syariahtidak dapat diterimaHasil penelitian menunjukkan bahwa kinerja direksi yang diukur dengan jumlah rapat dewan direksi tidak berpengaruh terhadap kinerja maqasid syariah. Hasil penelitian menunjukkan arah koefisien negatif yang artinya besarnya intensitas pertemuan yang dilakukan oleh direksi tidak menjamin kinerja perbankan syariah akan semakin tinggi. Hal ini kemungkinan disebabkan rapat yang dilakukan oleh direksi belum memfokuskan untuk membahas hal-hal terkait tujuan-tujuan sosial dari bank syariah. Hasil penelitian ini telah menolak hipotesis yang diajukan yaitu kinerja direksi berpengaruh positif terhadap kinerja maqasid syariah. Hasil temuan ini menolak hasil penelitian yang dilakukan oleh Ntim \& Osei (2011) yang menyatakan bahwa rapat dewan berpengaruh positif terhadap kinerja. Namun, penelitian serupa yang diungkapkan oleh Zahra dkk (2015) mengatakan bahwa jumlah rapat dewan tidak berpengaruh terhadap kinerja. Selain itu, penelitian yang diungkapkan oleh Widiastuti dan Wulan (2017) mengungkapkan bahwa struktur dan mekanisme direksi tidak berpengaruh tehadap islamicity financial performance index. Hal ini menandakan bahwa jumlah pertemuan yang dilakukan oleh direksi, tidak memberikan dampak yang positif terhadap tujuan sosial perbankan syariah. Seharusnya, dengan adanya rapat direksi dapat memberikan hasil yang positif untuk meningkatkan tujuan sosial dari perbankan syariah. Dengan demikian, pertemuan yang dilakukan oleh direksi masih belum berjalan secara efektif.

\section{KESIMPULAN DAN SARAN Kesimpulan}

Berdasarkan rumusan masalah dan pengujian terhadap hipotesis yang telah dilakukan serta analisis hasil penelitian dan pembahasan, maka dapat disimpulkan sebagai berikut:

1. Kinerja dewan komisaris tidak berpengaruh terhadap kinerja maqasid syariah

2. Kinerja DPS tidak berpengaruh terhadap kinerja maqasid syariah

3. Kinerja Direksi tidak berpengaruh terhadap kinerja maqasid syariah

\section{Saran}

Adapun saran untuk penelitian ini yakni:

1. Sebaiknya rapat dewan komisaris yang diadakan tidak terlalu berfokus dalam membahas pencapaian finansial saja tetapi perlu ditekankan pada tujuan yang diambil tidak hanya profit oriented tetapi juga falah oriented.Selain dalam memberikan nasihat kepada direksi, dewan komisaris perlu untuk meningkatkan pengetahuan yang tidak sebatas pada finansial saja tetapi juga sosial

2. Ketersediaan DPS dalam tata kelola perbankan syariah masih sangat terbatas. Selain itu, diperbolehkannya DPS untuk merangkap jabatan pada lembaga keuangan syariah lainnya menyebabkan kinerja DPS menjadi 
tidak efektif. Oleh karena itu, perbankan syariah hendaknya melakukan evaluasi terhadap DPS dalam tata kelola dengan menambahkan jumlah anggota DPS yang memenuhi kriteria yang telah ditetapkan.

3. Sebaiknya rapat dewan direksi di perbankan syariah dilaksanakan seoptimal mungkin untuk lebih membahas tujuan perbankan syariah yang dinilai dari segi tujuan yang memberikan benefit untuk seluruh pihak karena dewan direksi merupakan salah satu pihak menajemen yang diberikan amanah untuk menjalankan tugas dan tanggung jawabnya mengenai prinsipprinsip syariah.

\section{DAFTAR PUSTAKA}

Abidin, A Zainal;Alwi, N Mohd.; Arifin, N., Mohd. 2011. A Case Study on the Implementation of Qardhul Hasan Concept as a Financing Product in Islamic Banks in Malaysia. International Journal Of Economics, Management \& Accounting, Supplementary Issue 19: 81-100

Afrinaldi. 2013. Analisa Kinerja Perbankan Syariah Indonesia ditinjau dari Maqasid Syariah: Pendekatan Syariah Maqasid Index (SMI) dan Profitabilitas Bank Syariah. Islamic Economic \& Finance (IEF): Universitas Trisakti

Al Gifari, Muhamamad; Handoko, Luqman Hakim dan Yani, Endang Ahmad. 2015. Analisis Kinerja Perbankan Syariah di Indonesia dan Malaysia dengan Pendekatan Maqashid Indeks. Jurnal Ekonomi dan Perbankan Syariah, Vol. 3 No 2.

Antonio, Mohammad Syafii; Sanrego, Yulizar D dan Taufiq Muhammad. 2012. An Analysis of Islamic Banking Performance: Maqashid Index
Implementation in Indonesia and Jordania. Journal of Islamic Finance, Vol. 1 No. 1 (2012): IIUM Institute of Islamic Banking and Finance.

Bedoui, M. Houseem Eddine. 2012. Shari'A-Based Ethical Performance Measurement Framework. Chair For Ethics and Financial Norms.

Chariri,Charles. 2012. Analisis Pengaruh Islamic CorporateGovernance

Terhadap PengungkapanCorporate Social Responsibility. Diponegoro Journal of Accounting

Gestari, Intan. 2014.PengaruhGood Corporate Governance Dan Profitabilitas Terhadap Pengungkapan Islamic Social ReportingPada Bank Umum Syariah Di Indonesia. Naskah Publikasi. Universitas Muhammadiyah Surakarta

Hameed, Shahul et al. 2004. Alternative Disclosure and Performance Measures for Islamic Banks. Malaysia: IIUM.

Haryani, Rina Dwi. 2015. Analisis Pengaruh Kinerja Keuangan terhadap Tanggung Jawab Sosial Perusahaan Perbankan Yang Terdaftar di Bursa Efek Indonesia. Artikel Publikasi Ilmiah. Universitas Muhammadiyah Surakarta.

Kama,Ukpai\& Chuku, C.A. 2009. The Corporate Governance of Banks in Nigeria: How Effective are the Boards of Directors?.SSRN

Kharis, Abdul dan Suhardjanto, Djoko. 2012. Corporate Governance dan Ketaatan Pengungkapan Wajib pada Badan Usaha Milik Negara. Jurnal Keuangan dan Perbankan, Vol.16, No.1

Kholid dan Bachtiar. 2015. Pengaruh Dana Syirkah Temporer dan Good Corporate Governance terhadap Kinerja Maqasid Syariah Bank Syariah di Indonesia. Simposium Nasional Akuntansi 18 Universitas 
Sumatera Utara, Medan 16-19 September

Mohammed, Mustafa Omar; Razak, Dzuljastri Abdul \& Taib, Fauziah Md. 2008. The Performance Measures of Islamic Banking Based on the Maqashid Framework. Paper of IIUM International Accounting Conference (INTAC IV), Malaysia

Mohammed, Mustafa Omar \& Taib, Fauziah Md. 2015. Testing The Performance Meaasured Based on Maqashid alShariah (PMMS) Model on 24 Selected Islamic and Conventional Banks. Malaysia: IIUM.

Mokhtar, Hamim S Ahmad; Naziruddin, Abdullah; Al- Habshi, Syed M. 2006. Efficiency Of Islamic Banking In Malaysia: A Stochastic Frontier Approach .Journal of Economic Cooperation 27, 2 (2006) 37-70

Ntim, Collins G \& Osei, Kofi A. 2011. The Impact of Corporate Board Meetings on Corporate Performance in South Africa. African Review of Economics and Finance, Vol. 2, No. 2, pp.83103.

Rahayu, Ribut Sri; Cahyati, Ari Dewi.

2014. Faktor-Faktor Yang

Mempengaruhi Pengungkapan

CorporateSocial Responsibility

(CSR) Pada Perbankan Syariah.

$J R A K$, Vol. 5 No. 2 Agustus

2014Hal. 74-87

Satifa, Orisa dan Suprapto, Edy. 2014. Peran Dewan Pengawas Syariah dalam Pemenuhan Prinsip Syariah dalam Pelaksanaan Good Corporate Governance Pada Perbankan Syariah. Jurnal Ekonomi dan Perbankan Syariah

Suliyanto. 2011. Ekonometrika Terapan: Teori dan Aplikasi dengan SPSS. Andi: Yogyakarta

Widarjono, Agus. 2006. Ekonometrika Pengantar dan Aplikasinya Disertai Panduan Eviews Edisi Keempat. UPP STIM YKPN: Yogyakarta.
Widiastuti, Ayu; Wulan, Mulyaning. 2017. Good Governance Bisnis Syariah (Ggbs) Terhadap IslamicityFinancial Performance Index Bank Umum Syariah 2011-2015. Jurnal Ekonomi dan Bisnis, Vol. 1, No. 1

Widiawati, Septi. 2012. Analisis Faktorfaktor yang Mempengaruhi Islamic Social Reporting Perusahaanperusahaan yang Terdapat pada Daftar Efek Syariah Tahun 2009. 2011. Universitas Diponegoro

Zahra, Fajrina N; Pratomo, Dudi; Dillak, Valla J. 2015. The Effect Of Indepedent Directors, Board Size, And Frequency Of Board Meetings To Profitability. Telkom University 